\title{
Original Research
}

\section{Studi Kelayakan Pendirian Industri Ekstraksi Emas dari E-waste di Surabaya}

\author{
Zefanya Budijono $^{1 *}$, I Made Ronyastra ${ }^{1}$, Stefanus Soegiharto ${ }^{1}$ \\ ${ }^{1}$ Jurusan Teknik Industri, Fakultas Teknik, Universitas Surabaya, Raya Kalirungkut, Surabaya-Indonesia \\ 60293 \\ *corresponding author: zefa1997@gmail.com
}

\begin{abstract}
In this modern era along with the development of technology can not be separated from the waste produced. Waste from solid from technological development is electronic waste or often called e-waste. Along with the development of technology followed by an increase in e-waste in both developed and developing countries. E-waste itself is composed of a variety of substances from heavy metals to chemicals and even precious metal groups also make up the e-waste itself. It is said e-waste because it has not been used either because the technology has been left behind by the times, its performance has declined, or it cannot be used. Even so the constituent content in e-waste does not lose its value, one of which is precious metals that can be recycled. In this research, the opportunity to look at the use of precious metal content that is still valuable and can be taken from ewaste is gold, taking into account existing market share and methods for taking gold content in e-waste. This gold extraction activity from e-waste is more commonly known as urban mining outside Indonesia, because from the observations of researchers in Indonesia, especially in Surabaya, this business activity is still rarely an additional reason to conduct a feasibility study for the establishment of this industry in Surabaya. With the characteristics of the City of Surabaya it is assumed to supply qualifie $d$ raw materials for processing, besides that Surabaya is also one of the large market shares in Indonesia. In this research the method of extracting raw materials used is hydrometallurgy, because the product produced is gold so special security management was formed. In addition, because both raw materials and supporting materials in production are classified as B3, special management is also carried out related to waste treatment and worker safety in operational activities. At the founding of this industry capital came from bank loans and own capital with a ratio of 33:67 for a total project cost of $R p 1,455,738,638$. The IRR calculation results in this industry are greater than MARR that is 361\%> 10.48\%), for the NPV value obtained Rp 6,223,244,133.67, then with a 5 -year planning horizon only requires a DPP of 0.313891047 or about 3 months (smaller than the planning horizon for 5 years). For the sensitivity analysis the most important variables are the selling price and the cost of raw materials.
\end{abstract}

Keywords: e-waste, hydrometallurgy, industrial planning, feasibility study, urban mining

Abstrak-Pada era modern ini seiring perkembangan teknologi tidak lepas dari limbah yang dihasilkan. Limbah dari padat dari perkembangan teknologi adalah sampah elektronik atau yang sering disebut e-waste. Seiring perkembangan teknologi diikuti peningkatan e-waste baik di negara maju maupun negara berkembang. E-waste itu sendiri tersusun dari berbagai zat baik logam berat hingga zat kimia bahkan golongan logam mulia juga menjadi penyusun dari e-waste itu sendiri. Dikatakan e-waste karena sudah tidak digunakan baik karena teknologi tersebut sudah tertinggal oleh jaman, kinerjanya menurun, maupun sudah tidak dapat digunakan. Walaupun begitu kandungan penyusun pada e-waste tidak kehilangan nilainya salah satunya logam mulia yang dapat didaur ulang. Pada penelitian ini melihat peluang pemanfaatan kandungan logam mulia yang masih bernilai dan dapat diambil dari e-waste yang ada yaitu emas, dengan mempertimbangkan pangsa pasar yang ada serta metode dalam mengambil kandungan emas pada e-waste. Kegiatan mengekstraksi emas dari e-waste ini lebih sering dikenal dengan urban mining di luar Indonesia, karena dari pengamatan peneliti di Indonesia terutama di Surabaya kegiatan bisnis ini masih jarang me njadi tambahan alasan untuk melakukan penelitian studi kelayak pendirian industri ini di Surabaya. Dengan karakteristik Kota Surabaya diasumsikan pasokkan bahan baku mumpuni untuk diolah, selain itu Surabaya juga salah satu pangsa pasar yang besar di Indonesia. Pada penelitian ini metode pengekstraksian bahan baku yang digunakan adalah hidrometalurgi, karena produk yang dihasilkan adalah emas maka dibentuk manajemen keamanan khusus. Selain itu karena baik bahan baku dan bahan pendukung dalam produksi tergolong B3 maka juga dilakukan manajemen khusus terkait pengolahan limbah serta keselamatan pekerja pada kegiatan operasional. Pada pendirian industri ini modal berasal dari pinjaman bank dan modal sendiri dengan rasio 33:67 untuk total project cost sebesar Rp 1.455.738.638. Hasil perhitungan IRR pada industri ini bernilai lebih besar dari MARR yaitu 361\% > 10,48\%), untuk nilai NPV didapatkan Rp 6.223.244.133,67, maka dengan horizon perencanaan 5 tahun hanya memerlukan DPP sebesar 0,313891047 atau sekitar 3 bulan (lebih kecil dibandingkan horizon perencanaan selama 5 tahun). Untuk analisis sensitivitas variabel yang peling berpengaruh adalah harga jual dan biaya bahan baku.

Kata Kunci: e-waste, hidrometalurgi, perencanaan industri, studi kelayakan, urban mining

\section{PENDAHULUAN}

Di era modern ini Indonesia dengan jumlah penduduk mencapai 267 Juta jiwa memiliki pasar elektronik yang bertumbuh pesat terutama untuk smartphone maupun laptop/PC. Tingginya pertumbuhan tersebut tidak lepas dari meningkatnya $e$-waste atau limbah elektronik yang berasal dari alat elektronik yang dibuang karena tidak berfungsi atau sudah tidak dapat dipakai. Saat ini $e$ - waste merupakan permasalahan global yang terjadi di banyak negara baik negara maju maupun negara berkembang, hal tersebut dikarenakan ketidakseimbangan 
antara kecepatan dan teknologi pengolahan e-waste dengan produksi e-waste ini sehingga lebih cepat menumpuk pada tempat pembuangan akhir (TPA). Disamping itu kemajuan teknologi yang pesat pada tahapan pembaharuannya memaksa untuk meninggalkan teknologi yang sudah usang (Binus, 2016).

E-waste ini sendiri terdiri dari beragam jenis material yang sebagian besar adalah logam berat yang masih terdapat banyak jenisnya mulai dari merkuri, timbal, kobalt, palladium, perak, tembaga, hingga emas dan material lainnya. E-waste ini sendiri sebagian besar tergolong sebagai B3 (bahan beracun dan berbahaya) karena paparan limbah ini dapat menganggu kesehatan manusia dan hewan. Volume dari e-waste rata-rata pertahun meningkat mencapai 3-5\%, bahkan saat ini 5\% limbah padat yang dihasilkan dunia adalah $e$ waste (Jehan, 2012). Menurut data dari PBB masyarakat dunia menghasilkan 44,7 juta ton sampah elektronik pada tahun 2016 dan selalu meningkat 3-4\% pertahun dan diperkirakan pada tahun 2021 mencapai 52 juta ton.

Berdasarkan data BPS pada tahun 2012 untuk produksi komputer dapat mencapai 12 juta/tahun dan jumlah impor mencapai 35 ribu/tahun, sehingga dari jumlah tersebut secara potensial menghasilkan e-waste dengan jumlah yang besar (Jehan, 2012). Jika dilihat berdasarkan kandungan pada e-waste, terdapat salah satu logam mulia yang masih memiliki nilai jual adalah emas. Emas merupakan salah satu sumber daya alam yang tidak dapat diperbaharui sehingga seiring berjalannya waktu mengalami peningkatan harga karena kebutuhan akan emas cukup tinggi dan terus meningkat mulai sebagai perhiasan hingga material dalam pembuatan komponen alat elektronik. Emas sebagai konduktor listrik zero resistensi sering digunakan sebagai bahan pelapis pada bagian-bagian tertentu komponen elektronik seperti processor, harddisk, chip handphone, motherboard, RAM, IC, dan lainnya.

Menurut World Gold Council pada tahun 2019 di kuartal 1 kebutuhan emas mengalami kenaikan sebesar 7\% sehingga kebutuhan total menjadi sebesar 1.053,3 ton (Goldhub, 2019), sedangkan untuk produksi emas seperti pada gambar 1.1 untuk produksi emas berasal dari pertambangan dalam 10 gram emas membutuhkan batuan tambang sebanyak 1 ton dan produksi emas dari urban mining (pengolahan e-waste) untuk 1 ton bahan baku dapat menghasilkan kurang lebih 1000 gram emas berdasarkan proses dan teknologi yang digunakan (MWX, 2017). Dapat kita lihat bahwa produksi emas dan kebutuhan akan emas kurang berjalan seimbang, dimana kebutuhan akan emas tinggi baik untuk perhiasan, keperluan komponen elektronik, dan instrumen investasi. Sedangkan untuk produksi emas dari alam untuk pertambangan stok persediaan emas menipis dan untuk memperoleh emas cukup sukar dan membutuhkan batuan tambang dengan jumlah yang besar. Dengan adanya kandungan emas pada peralatan elektronik menjadikan e-waste berpotensi untuk dilakukan pengolahan untuk mengambil nilai sisa suatu e-waste semaksimal mungkin.

Kota Surabaya adalah salah satu kota metropolitan yang berpotensi dalam pengahasil $e$-waste. Hal tersebut dikarena penduduknya memiliki kecenderungan konsumtif. Semakin majunya teknologi berakibat meningkatnya prilaku penduduk untuk beralih kepada teknologi yang lebih terbaru. Hal itu menyebabkan ditinggalkannya perlengkapan teknologi yang lama, dimana teknologi yang ditinggalkan berpotensi menjadi e-waste. Menurut Kasi Pengawasan dan Penataan Hukum Dinas Lingkungan Hidup (DLH) City Mangozong pada wawancara Jawa Pos 29 Januari 2018 potensi limbah di Surabaya cukup besar, namun DLH masih dalam tahap mengidentifikasi besaran potensi limbah elektronik di Surabaya. Besaranya sampah elektronik salah satu penyebabnya tidak diolahnya kembali limbah elektronik yang dihasilkan oleh produsen (Jawa Pos, 2018).

Adanya kandungan emas pada e-waste, dimana karakteristik dari emas itu sendiri memiliki nilai jual yang tidak pernah mati akan emas menjadikan ide untuk mengambil nilai jual yang masih tersisa. Dengan mendirikan sebuah industri ekstraksi emas dari $e$ - waste besar harapan untuk memperoleh keuntungan dengan peluang belum banyak industri sejenis di Surbaya dan melihat ketersediaan bahan baku dianggap berpeluang besar untuk merealisasikan ide ini. Untuk memastikan ide pendirian industri ekstraksi emas dari e-waste ini 
perlu dibutuhkan studi kelayakan dengan mempertimbangkan aspek-aspek yang dibutuhkan apakah layak tidak untuk merealisasikan ide ini.

Pada pemanfaatan e-waste yang akan dilakukan menggunakan metode hidrometalurgi. Metode ini menggunakan bahan kimia untuk prosesnya, dengan menghasilkan reaksi kimia yang meleburkan e-waste dan menyisakan endapan emas yang selanjutnya akan dilebur menjadi emas padat (Rofika, dkk. 2018). Metode hidrometalurgi ini akan menggunakan carian kimia aqua regia, yang selama ini dikenal sebagai metode melarutkan emas. Dari emas yang dilarutkan dengan bahan baku e-waste kadar emas yang akan dihasilkan memiliki tingkat kemurnian $99 \%$. Karena e-waste berkaitan dengan teknologi maka dibutuhkan kualitas emas terbaik, sehingga kandungan emas pada $e$-waste memiliki kemurnian yang tinggi.

Dari metode hidrometalurgi yang digunakan untuk ekstraksi emas dari e-waste akan meninggalkan zat sisa yang sudah tidak digunakan karena hanya kandungan emasnya saja yang digunakan, selanjutnya zat sisa tersebut akan menjadi limbah dari proses produksi. Limbah yang dihasilkan akan dialihkan kepada pihak kedua yang bergerak dibidang jasa pengolahan limbah baik kimia maupun padat.

\section{METODE}

\section{A. Pengamatan Awal}

Pengamatan awal dilakukan untuk melihat pasar dari hasil proyek serta melakukan pengamatan terhadap sumber bahan baku dalam proyek ini, yang dapat dilakukan menggunakan wawancara maupun observasi.

B. Identifikasi Masalah

Dari pengamatan awal dilakukan identifikasi terkait masalah apa yang sedang terjadi dan dibuat rumusan masalah untuk diselesaikan dengan meninjau dari aspek pasar, aspek teknis, aspek manajemen, dan aspek keuangan. Dimana adanya peluang pengambilan material logam yang masih bernilai di e-waste yang selama ini laju pertumbuhannya lebih tinggi daripada laju pengolahannya.

\section{Tujuan Penelitian}

Setelah mengidentifikasi masalah dan merumuskan masalah selanjutnya ditentukan tujuan penelitian ini yaitu melakukan studi kelayakan pendirian industri terkait ekstraksi emas pada e-waste yang terdapat di kota Surabaya.

D. Studi Kepustakaan

Setelah tujuan penelitian ditentukan dilakukan studi kepustakaan untuk mendukung segala informasi yang dibutuhkan baik refrensi buku, jurnal, dan sumber terpecaya lainnya agar studi kelayakan yang dilakukan memiliki pedoman yang terstruktur serta mempermudah proses analisis pendirian industri ini terhadap aspek yang perlu dipertimbangkan mulai dari aspek teknis, aspek pasar, aspek manajemen, dan aspek keuangan. Refrensi terkait metode yang digunakan yaitu hidrometalurgi akan diproleh dari hasil pengamatan dari pengalaman beberapa sumber yang lebih ahli dipraktek nyata dibidang ini.

\section{E. Pengumpulan Data}

Pengumpulan data digunakan untuk menunjang pengambilan keputusan yang akan dilakukan, dalam hal ini data dibagi menjadi dua yaitu data primer dan data sekunder. Untuk data primer dapat diperoleh dengan menggunakan survei, wawancara, maupun observasi, sedangkan untuk data sekunder didapat dari refrensi media elektronik maupun cetak.

- Aspek pasar: Pangsa pasar, kebutuhan akan bahan baku

- Aspek teknis: Lokasi usaha, luas tanah dan bangunan, tata letak ruangan, perlengkapan dan fasilitas yang dibutuhkan, metode yang digunakan

- Aspek manajemen: Bentuk badan hukum, perijinan, struktur organisasi, jumlah tenaga kerja

- Aspek keuangan: Biaya sewa tanah dan bangunan, biaya perizinan, biaya perlengkapan dan peralatan, biaya gaji biaya listrik dan air 


\section{F. Pengolahan Data dan Analisis Data}

Pengolahan data dan analisis data dilakukan terhadap aspek yang menjadi bahan pertimbangan terhadap kelayakan proyek ini untuk diketahui layak atau tidak layaknya, yaitu aspek pasar, aspek teknis, aspek manajemen, dan aspek keuangan.

G. Kesimpulan dan Saran

Dengan melihat hasil analisis data maka dibuatlah kesimpulan terhadap studi kelayakan yang dilakukan untuk menjawab layak atau tidak layaknya poyek ini, serta memberikan penjelasan untuk setiap hasil akhir baik jika proyek ini layak ataupun jika proyek ini tidak layak, dan memberikan saran untuk hasil dari studi kelayakan yang dilakukan.

\section{HASIL}

\section{Aspek Pasar}

Dalam berjalannya proses bisnis ini emas yang diproduksi dapat diterima oleh pasar berapapun jumlahnya, hanya perlu disesuaikan oleh harga pasar yang ada. Untuk penentuan harga emas dipengaruhi oleh tingkat kurs dollar dan perang dagang. Dalam hal ini akan dilakukan peramalan dengan data yang diperoleh dari Laporan tahunan PT Antam Tbk sebagai gambaran acuan terhadap aspek pasar. Dari hasil peramalan diperoleh estimasi harga jual emas untuk horizon 5 tahun yaitu mulai dari tahun 2020- 2024.

Tabel 1

Forecast Harga Jual Emas Periode 2020-2024 (Gram/Rupiah)

\begin{tabular}{ll}
\hline Tahun & Harga Jual (Gram/Rp) \\
\hline 2020 & 644.058 \\
2021 & 667.484 \\
2022 & 691.260 \\
2023 & 715.385 \\
2024 & 739.859 \\
\hline
\end{tabular}

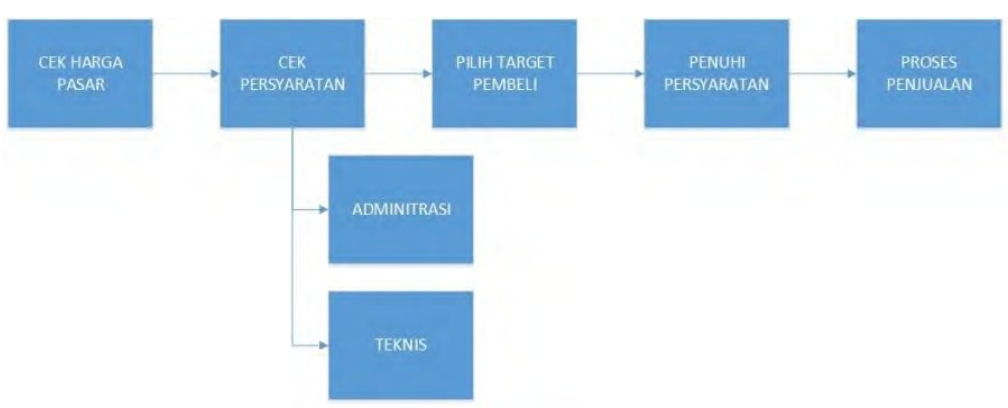

Gambar 1. Proses penjualan.

Pada Gambar 1 dapat dilihat proses penjualan yang dilakukan pada proses bisnis, dengan pangsa pasar yang dituju PT Antam Tbk. Namun tidak menutup kemungkinan ditujukan ke pasar lainnya melihat pangsa pasar dari emas luas. 
Aspek Teknis

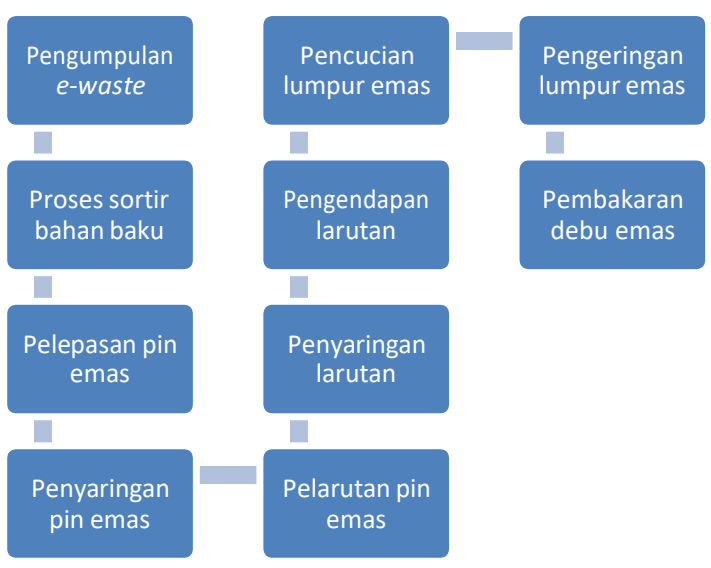

Gambar 2. Proses produksi.

Pada Gambar 2 menunjukan alur dari proses produksi yang dilakukan. Untuk e-waste yang digunakan difokuskan kepada 3 jenis yaitu RAM, Processor, dan Motherboard. Untuk ketersediaan bahan baku sendiri berdasarkan hasil penelitian Herdayuli (2013) ditemukan bahwa potensi limbah elektronik pada tahun 2015 sebesar 2440 ton/tahun dengan prosentase $60 \%$ adalah barang elektronik laptop dengan wilayah cakupan yaitu Kenjeran, Krembangan, Pabean Cantikan. Sedangkan menurut Fentika dan Mirwan (2018) potensi limbah elektronik pada tahun 2021 sebesar 366,842 ton/tahun dengan prosentase 96,25\% adalah barang elektronik laptop dengan wilayah cakupan yaitu Tambak Wedi, Bulak Benteng, Kedinding, dan Sidotopo Wetan. Lokasi yang dipilih pada penelitian ini berada di wilayah Tambak Sari, Surabaya dengan luas 200 meter persegi dan biaya sewa $60 \mathrm{Jt}$ per tahun.

\section{Aspek Manajemen}

Dalam berjalanannya kegiatan operasional diperlakukan sistem keamanan khusus, mengingat hasil produksi dari kegiatan bisnis ini adalah emas. Sistem keamanan dimulai dari personel yang digunakan. Kepala satpam berasal dari purna TNI atau anggota TNI yang dikaryakan, hal itu dikarenakan TNI lebih berpengalaman dalam hal pengamanan. Untuk anggota satpam sendiri terdiri dari wanita dan pria untuk mempermudah saat bertugas dilapangan, anggota satpam terdiri dari warga sekitar perusahaan dan anggota yang memiliki latar belakang pendidikan satpam dengan begitu ketika terjadi hal yang tidak diinginkan dengan warga sekitar perusahaan dapat mempermudah proses mediasi dan juga sangat penting kemampuan satpam dengan berdasarkan pendidikan satpam. Untuk shift kerja satpam berbeda dari karyawan lain, dimana satpam dalam 1 shift bekerja selama 12 jam dengan 3 satpam setiap shiftnya. Shift kerja dimulai dari jam 7 pagi hingga 7 malam setiap harinya, dalam 1 hari berisi 2 shift kerja. Untuk kepala satpam akan bekerja sama seperti jam operasional, namun jika ada hal mendesak diluar jam operasional maka kepala satpam akan segera merapat. Untuk satpam wanita akan selalu bekerja di shift awal menyesuaikan jam operasional yang berada di shift awal.

Untuk memantau keamanan dalam perusahaan, dilakukan periksa tubuh pada saat datang maupun meninggalkan perusahaan. Pemeriksaan dilakukan diruangan tertutup sesuai dengan prosedur dan etika pemeriksaan badan. Setiap karyawan baik bagian produksi dan non produksi dilakukan pemeriksaan yang sama untuk memastikan keamanan yang maksimal. Untuk menunjang sistem keamanan selain melakukan pemeriksaan badan dan pengawasan berkala dengan berkeliling, perusahaan dilengkapi dengan CCTV sebanyak 8 buah yang lebih banyak memantau aktivitas produksi. Untuk kualitas CCTV dioptimalkan dengan penggunaan alat yang berkualitas. Selain itu penggunaan HT juga dipilih sebagai media komunikasi yang langsung dan dapat terhubung dengan bagian kantor dan bagian produksi. 
Pada proses bisnis ini untuk bahan baku produksi adalah salah satu limbah B3 serta menggunakan zat-zat kimia yang berbahaya antara lain $\mathrm{HCL}$ dan Asam Nitrat. Dengan proses pengolahan baku dengan metode hidrometalurgi akan menghasilkan limbah yang dapat berbaya bagi kesehatan lingkungan jika tidak ditangani dengan benar. Karena itu ada yang namanya staf K3 dimana bertugas mengurusi kesehatan dan keselamatan kerja termasuk urusan limbah. Untuk menghemat dan fokus kepada proses bisnisyang ada maka limbah yang dihasilkan akan dialihkan kepada pihak kedua yang bergerak dibidang penampungan, pengangkutan, dan pengolahan limbah. Pihak kedua yang dipilih dalam pengangkutan, penampungan, dan pengolahan limbah sudah pasti mengantongi perizinan khusus sesuai peraturan pemerintah nomor 101 tahun 2014 tentang pengolahan limbah bahan berbahaya dan beracun.

Limbah yang dihasilkan pada proses produksi adalah limbah padat sisa bahan baku yang tidak digunakan karena tidak bernilai, limbah cair hasil dari pelarutan bahan baku dengan menggunakan $\mathrm{HCL}$ dan asam nitrat, dan juga ada gas reaksi kimia pada saat campuran $\mathrm{HCL}$ dan asam nitrat disatukan dengan bahan baku. Untuk larutan aqua regia sendiri dapat dibuang langsung kesaluran pembungan dengan menetralkannya terlebih dahulu, namun karena pada proses produksi aqua regia sudah bercampur dengan bahan baku yang mengandung logam maka larutan aqua regia yang sudah terkontaminasi logam harus dikumpulkan untuk dilakukan penetratilasian khusus. Limbah pada proses produksi akan disimpan pada drum besi dan diletakkan pada ruangan khusus yang disesuaikan dengan kriteria dari peraturan pemerintah tentang limbah B3.

\section{Aspek Keuangan}

Tabel 2

Perhitungan MARR

\begin{tabular}{lccccc}
\hline $\begin{array}{l}\text { Struktur } \\
\text { Pembiayaan }\end{array}$ & Persentase & Besar Dana (Rp) & $\begin{array}{c}\text { Cost of } \\
\text { Capital }\end{array}$ & $\begin{array}{c}\text { Risk } \\
\text { Premium }\end{array}$ & MARR \\
\hline Modal Sendiri & $67 \%$ & 955.738 .638 & $7 \%$ & $3 \%$ & $10,48 \%$ \\
Pinjaman Bank & $40 \%$ & 500.000 .000 & $10 \%$ & & \\
\hline
\end{tabular}

Pada tabel 2 menunjukkan total project cost untuk bisnis ini dan pembagian proporsi antara modal sendiri dan pinjaman bank. Dari MARR yang diperoleh selanjutnya akan dibandingkan dengan IRR untuk melihat layak tidaknya proses bisnis ini dari segi keuangan.

Tabel 3

Perhitungan Valuasi

\begin{tabular}{|c|c|c|c|c|c|c|}
\hline & Pra Operasi & 2020 & 2021 & 2022 & 2023 & 2024 \\
\hline $\begin{array}{l}\text { Fix Investment } \\
\text { Cost }\end{array}$ & (94.114.699) & & & & & \\
\hline $\begin{array}{l}\text { Venture } \\
\text { InitiationCost }\end{array}$ & $(333.660 .800)$ & & & & & \\
\hline $\begin{array}{l}\text { Net Cashflow } \\
\text { dari Operasi }\end{array}$ & 0 & $\begin{array}{c}1.505 .587 .5 \\
31 \\
\end{array}$ & 1.650.158.059 & $\begin{array}{c}1.800 .493 .46 \\
7 \\
\end{array}$ & $\begin{array}{c}1.956 .624 \\
.053 \\
\end{array}$ & 2.118 .564 .993 \\
\hline Nilai Sisa & & & & & - & \\
\hline CASH FLOW & (427.775.499) & $\begin{array}{c}1.505 .587 .5 \\
31\end{array}$ & 1.650 .158 .059 & $\begin{array}{c}1.800 .493 .46 \\
7\end{array}$ & $\begin{array}{c}1.956 .624 \\
.053\end{array}$ & 2.118 .564 .993 \\
\hline
\end{tabular}




\begin{tabular}{|c|c|c|c|}
\hline $\begin{array}{l}\text { NET PRESENT } \\
\text { VALUE }\end{array}$ & $\begin{array}{l}6.223 .244 .133 \\
, 67\end{array}$ & LAYAK & \\
\hline IRR & $361 \%$ & $\begin{array}{l}\text { Layak } \\
\text { karena } \\
\text { lebih besar } \\
\text { dari } \\
\text { MARR } \\
\end{array}$ & \\
\hline \multirow[t]{2}{*}{ DPP } & 0,313891047 & Tahun & Lebih kecil dari Horison Perencanaan berarti Layak \\
\hline & 3,766692563 & Bulan & \\
\hline
\end{tabular}

Pada tabel 3 dapat dilihat kelayakan bisnis ini dari segi keuangan dengan NPV menunjukkan nilai positif, IRR lebih besar dari MARR, dan DPP lebih kecil dari horizon perencanaan.

\section{BAHASAN}

\section{Aspek Pasar}

Pada bagian pangsa pasar emas memiliki pasar yang luas mulai dari kebutuhan industri perhiasan, instrumen investasi, hingga keperluan industri elektronik. Hal ini membuat produk yang dihasilkan dapat diserap pasar dengan baik.

\section{Aspek Teknis}

Pasokkan bahan baku e-waste merupakan faktor kritis pada penelitian ini. Hal tersebut karena dibutuhkan usaha ekstra dalam mendapatkan bahan baku. Berdasarkan beberapa penelitian bahan baku e-waste ini memiliki volume yang besar namun hanya sebagian saja yang sementara terkumpul oleh pengepul hal itu disebabkan kurangnya jembatan antara pihak penghasil $e$-waste dengan tempat pembuangan/penyalur dari e-waste ini. Sehingga dibutuhkan pengkondisian khusus terkait distribusi dan pengumpulan bahan baku dari pihak pengepul.

\section{Aspek Manajemen}

Pada proses bisnis ini produk yang dihasilkan adalah emas, sehingga dibutuhkan manajemen khusus untuk menjaga keamanan dari produk yang dihasilkan. Selain itu dari proses produksi awal hingga akhir yang berkaitan dengan limbah B3 dibutuhkan sebuah sistem manajemen khusus untuk menjaga keamanan dan keselamatan kerja.

\section{Aspek Keuangan}

Setelah dilakukan analisis sensitivitas ditemukan bahwa variabel yang sensitif adalah harga jual, biaya bahan baku. Dalam persaingan memperoleh bahan baku e-waste diperlukan tawar menawar kepada pihak supplier, dalam hal tersebut dibutuhkan batasan harga maksimal yang dapat dikeluarkan untuk memperoleh bahan baku. Selain itu untuk memperoleh profit yang tinggi juga perlu dilakukan perhitungan waktu terbaik untuk menjual produk dan lama produk dapat disimpan untuk menjaga harga jual.

\section{SIMPULAN}

\section{Aspek Pasar}

Aspek pasar pada pendirian industri ini dikatakan layak hal itu karena produk yang dijual adalah emas. Emas memiliki pangsa pasaryang besar dan luas. Emas yang dihasilkan juga memiliki kualitas yang baik selain itu tren harga jual dari emas cenderung naik setiap tahunnya. Karakteristik emas yang merupakan logam mulia serta sumber daya alam yang tidak dapat diperbaharui juga membuat pasar akan menerima semua hasil produksi yang dipasarkan. Pangsa pasar yang ada juga tersebar luas dan jumlahnya banyak, sehingga tidak akan kekurangan pembeli. 


\section{Aspek Teknis}

Untuk pemilihan lokasi berada dekat dengan sumber bahan baku dan memiliki faktor pendukung yang mumpuni seperti ketersediaan listrik, air, dan sumber daya manusia. Untuk proses pengolahan bahan baku tidak membutuhkan tahapan-tahapan yang rumit serta peralatan khusus yang sukar dicari atau digunakan. Dalam bisnis ini terdapat resiko produksi manusia (kelalaian dalam bekerja, penggunaan alat-alat) hal ini diatasi dengan alat pengaman, sop, pengawas dan K3. Dari segi aspek teknis pendirian industri dapat dikatakan layak.

\section{Aspek Manajemen}

Berdasarkan struktur organisasi yang dibentuk tugas dan tanggungjawab dibagi sesuai dengan kapasitas dan kemampuan yang dibutuhkan untuk menjaman berjalannya kegiatan operasional yang sistematis dan terawasi. Dalam pengamanan dan limbah pun juga disiapkan proses manajemen khusus untuk menjamin keamanan dari produk yang dihasilkan dan juga limbah yang terbentuk, hal tersebut karena emas sebagai produk akhir harus diamankan dengan baik serta limbah yang bersifat beracun dan berbahaya harus ditangani dengan seksama. Dari segi manajemen pendirian industri dapat dikatakan layak.

\section{Aspek Keuangan}

Pada industri ini untuk pemodalan di Total Project Cost digunakan modal sendiri sebesar Rp 955.738 .638 (67\%) dan peminajaman kepada bank sebesar Rp 500.000.000 (33\%). Hasil perhitungan IRR yang dilakukan didapatkan nilai IRR > MARR $(361 \%>10,48 \%)$, dengan NPV sebesar Rp 6.223.244.133,67, maka didapatkan DPP selama 0,313891047 tahun sedangkan horizon 5 tahun. Dari segi keuangan pendirian industri dapat dikatakan layak.

Untuk analisis sensitivitas jatuh pada harga jual PT Antam Tbk. dan biaya bahan baku. Untuk analisis rasio aktifitas walau untuk FATO mengalami penurunan tapi jika dilihat dari pendapatan bersih selalu meningkat, Untuk analisis rasio profitabilitas tidak mengalami kerugian karena selalu mengalami peningkatan profit setiap tahunnya, dan untuk analisis rasio solvabilitas hutang dapat dibayar dengan baik tepat pada waktunya.

\section{PUSTAKA ACUAN}

Antrekowitsch, H., M., Spruzina, W., Proir, F., (2006), Metallurgical Recycling of Electronik Scrap, The Mineral, Metal, and Materials Society, EPD Congress 2006

Deubzer, O. (2011). E-waste management in Germany (UNU-ISP). Bonn: Operating Unit SCYCLEUN Campus Bonn - Langer EugenHermann-Ehlers-Str. 10D53113.

Fentika, H. J \& Mirwan, M. (2018). Peran serta Masyarakat Dalam Pengelolaan Sampah Elektronik di Wilayah Surabaya Utara. Jurnal Envirotek Vol (8) No. (2).

Natesh, p.p, Govindaradjane, S. and Pradeepkumar, S., 2005. Methodological review on recovery of gold from E-waste in India. Chemical and Pharmaceutical Sciences, 8(2), pp.1-5.

Hamali, A. Y. (2016). Pemahaman Strategi Bisnis \& Kewirausahaan (1st ed.). Jakarta: Kencana Prenada Media Group.

Herlianto, D.\& Triani, (2009), Studi Kelayakan Bisnis, edisi ke-1, cetakan ke-1, Yogyakarta: Graha Ilmu.

Herdayuli (2013), "Potensi Timbulan Sampah Elektronik dari Rumah Tangga dan Penanganannya di Wilayah Surabaya Utara". Surabaya: Teknik Lingkungan ITS.

Husnan. Suad \& Suwarsono (1991), STUDI KELAYAKAN PROYEK, AMP YKPN, Yogyakarta.

Kasmir \& Jakfar, (2003), Studi Kelayakan Bisnis, edisi revisi, cetakan ke-10, Jakarta: Kencana Prenada Media Group. 
Kottler, Philip dan Armstrong, Gary, (2004), Principles of Marketing , Tenth Edirion, New Jersey, Prentice Hall.

Nitisemito dan Burhan, (2004), Wawasan Studi Kelayakan dan Evaluasi Proyek, Jakarta, PT Bumi Aksara.

Rofika. Fitrotul \& Rachmanto. A. T (2018), PROSES HIDROMETALLURGI MEGGUNAKAN PELARUT AQUA REGIA PADA RECOVERY LOGAM EMAS (Au) LIMBAH ELEKTRONIK PCH HP, Vol. 9 No. 1, pp. 63-64.

Sutojo, Siswanto, Project Feasibility Study, Edisi keempat, Penerbit PT Damar Mulia Pustaka, Jakarta, 2006 Umar. Hussein (1997), STUDI KELAYAKAN BISNIS, PT Gramedia Pustaka Utama, Jakarta.

Goldhub (2019), GOLD DEMAND TRENDS Q1, Online: https://www.gold.org/goldhub/research/gold-demand-trends/gold-demand- trends-q12019 (Akses 10 Juni 2019)

Golden Scrap (2019), https://goldenscrap.com (Akses 10 Juni 2019)

MWX (2017), THE FUTURE OF MINING: URAN MINING, Online: https://www.streetwisereports.com/article/2017/11/23/the-future-of-mining-urban mining.html (Akses 10 Juni 2019)

Jehan (2012), KANDUNGAN BERBAHAYA DALAM E-WASTE, Online: http://ylki.or.id/2012/09/kandungan-berbahaya-dalam-e- waste/ (Akses 10 Juni 2019)

Binus (2016), ADA EMAS DALAM SAMPAH ELEKTRONIK, Online: https://sis.binus.ac.id/2016/09/27/ada-emas-dalam-sampah- elektronik/ (Akses 10 Juni 2019)

Jeko (2019), JUMLAH SAMPAH ELETRONIK BAKAL BERTAMBAH HINGGA 52 JUTA TON PADA 2012, Online:

http://www.Liputan6.com/tekno/read/3947173/jumlah-sampah-elektronik-bakal bertambah-hingga-52-juta-ton-pada-2021 (Akses 10 Juni 2019)

Yugi (2019), Bentuk-bentuk badan usaha, Online : www.eduspensia.id/bentuk-bentuk-badanusaha/ (Akses 13 November 2019) Izin (2018), Online: https://izin.co.id/artikel/syaratpendirian-pt.php (Akses 13 November 2019)

PTSP Kementrian LHK R I (2019), Izin Pemanfaatan Limbah B3, Online: http://pelayananterpadu.menlhk.go.id/index.php/izin-pemanfaatan-limbah-b3\#1 (Akses 13 November 2019)

Liputan 6 (2019), Wow, Timbunan Emas Tersebar di Jawa Timur, Online: http://m.liputan6.com/regional/read/3886736/wow- timbunan-emas-tersebar-di-jawatimur (akses 20 Desember 2019) 